Acta vet. scand. 1977, 18, 40- 53 .

From the Research Station of the Veterinary Institute, Skara, Sweden.

\title{
AGAROSE GEL ELECTROPHORETIC FRACTIONATION OF SERUM PROTEINS IN ADULT CATTLE
}

I. A STUDY OF CLINICALLY HEALTHY COWS *

\author{
By \\ Per Liberg
}

\begin{abstract}
LIBERG, PER: Agarose gel electrophoretic fractionation of serum proteins in adult cattle. I. A study of clinically healthy cows. Acta vet. scand. 1977, 18, 40-53. - Blood samples were taken from 25 clinically healthy Swedish red-and-white dairy cows on 11 occasions in the course of about one year. The blood serum proteins were studied, chiefly by agarose gel electrophoresis, in respect of relative and absolute concentrations. The following parameters were studied: Total protein, albumin, total globulin, $\mathbf{A} / \mathbf{G}$ quotient, $\alpha_{1^{-}}, \alpha_{2-}$, inter- $\alpha-\beta-, \beta_{1^{-}}, \beta_{2^{-}}$and $\gamma$-globulin. The material was analysed statistically in respect of variation between and within cows, and of age, pregnancy and seasonal variation. The variation between cows was found to be significantly greater than that between different samplings of the same cow. Older cows exhibited significantly higher $\gamma$-globulin concentrations. The variation with season and stage of pregnancy was less pronounced for most serum protein fractions.
\end{abstract}

agarosegel electrophoresis; bovine serum proteins; normal values.

Electrophoretic protein fractionation for diagnostic purposes has not been developed to the same extent in veterinary as in human medicine. Paper electrophoresis has been used in most animal studies (e.g. Boguth 1954, Chopard 1954, Zimmerli 1955, Wünsche 1960). Paper electrophoresis suffers from certain weaknesses such as poor resolution and disturbing adsorption phenomena. Distinct separation of different components in bovine

* The investigation was supported by the Swedish Council for Forestry and Agricultural Research. 
serum may be difficult to achieve. Labouche (1962) found for example that the $\alpha$-globulin peak very often was not clearly visible and that the $\beta$-globulin was not distinctly separated from the $\gamma$-globulin. Irfan (1967), furthermore, found that a $\gamma$-globulin component lay very close to the $\beta$-globulin.

Methods have been developed in which cellulose acetate, polyacrylamide gel or agar gel are used as separation medium. These media permit rapid separation with improved resolution. For study of bovine serum such methods have been used only by a few investigators (Matthaeus 1965, Ek 1969, Osbaldiston 1972, Raphael et al. 1973, McLennan \& Willoughby 1973).

To further increase the efficiency and usability of agar gel electrophoresis a technique has been developed which uses separation in agarose gel on water-cooled glass plates (Johansson 1972.

This technique has been modified for study of bovine serum (Carlström \& Liberg 1975). The agarose gel electrophoresis method is simple and quick. The resolution is sufficiently good to allow a naked-eye estimate of the concentrations of individual proteins in the different electrophoretic zones. A more objective evaluation can be made spectrophotometrically by so-called gel scanning.

Evaluation of the electrophoretic patterns requires knowledge as to which proteins are main components in each fraction and as to the variation of the different proteins in health and in disease. Genetic and acquired protein variants may shift the mutual positions of the proteins. It may therefore be difficult to interpret the signification of a changed peak.

Normal values for the protein fractions in bovine serum reported in the literature are with few exceptions based on paper electrophoresis. They show great variation, largely attributable to differences in separation technique and quantizing procedures. For this reason several authors have maintained that each laboratory should determine its own normal values for the animal population to be studied (Nilsson \& Ảberg 1956, Haraszti \& Tölgyesi 1961, Ek, Osbaldiston).

Normal values vary also with factors such as breed, age, stage of lactation and of pregnancy. Individual values found in diseased states must therefore be judged in relation to these factors. The changes which appear to be most pronounced are increasing concentrations of total protein and $\gamma$-globulin with rising age 
(e.g. Winkler 1955, Czernicki 1957, Perk \& Loebl 1959, Matthaeus \& Straub 1965, Heidler 1968) and lowering of the serum protein concentrations during the very last stage of pregnancy (Larson \& Kendall 1957, Larson 1958, Larson \& Hays 1958, Haraszti \& Tölgyesi, Carlström 1961, McLennan \& Willoughby 1973). In cattle, furthermore, large variations have been found between individual animals, and even in the same animal on different occasions.

The object of this investigation has been to determine normal values of serum proteins in Swedish adult cattle by means of agarose gel electrophoresis and to some extent to study also the physiological variation for the animal population concerned.

\section{MATERIALS AND METHODS}

The material consisted of 25 Swedish red-and-white dairy cows from five herds with medium to high production. Blood samples were taken from all animals on 11 occasions at five weeks' interval during about one year. The animals were clinically healthy throughout the period of the study. The blood was centrifugated as soon as possible. The serum samples were stored at $-20^{\circ} \mathrm{C}$ before analysis.

Total protein was determined by the biuret method.

Albumin was determined spectrophotometrically with bromcresol green (Doumas et al. 1971).

Total globulin concentration and albumin/globulin ratio were calculated on the basis of total protein and albumin values.

Electrophoresis was run ad modum Carlström \& Liberg (1975) (Agarose gel, barbital buffer, $\mathrm{pH} 8.6$ + barbital hydrochloric acid buffer, $\mathrm{pH} 7.9,20 \mathrm{v} / \mathrm{cm}$, about $40 \mathrm{~min}$ ). Evaluation of the electrophoresis pictures was done in a Beckman spectrophotometer Acta CIII with gel scanner and integrator recorder. The electrophoresis picture was divided into the following fractions: $\alpha_{1}-, \alpha_{2}-$, inter- $\alpha-\beta-, \beta_{1}-, \beta_{2}-$ and $\gamma$-globulin (Fig. 1).

As the albumin zone becomes relatively very heavily stained in electrophoresis, the optical measurement usually underestimates the albumin concentration. The correlation between electrophoretic and wet-analytical determination of albumin as above was therefore calculated. The coefficient of correlation was 0.75 and the coefficient of regression $\mathbf{0 . 6 6}$. There is reason to consider the higher albumin values found in wet-analytical determination 
more correct. In the electrophoresis picture, therefore only the relative concentration of different globulins was taken into account. The absolute concentration was calculated on the basis of the calculated total globulin concentration.

The reproducibility of the electrophoretic method was investigated by determination of the variations of double samples on different electrophoresis plates (interplate variation). Twentyfour normal double samples were run and the analytical variation ( $=S a)$ was evaluated using the formula: $S a=\sqrt{\frac{\overline{\Sigma d^{2}}}{2 n}}$ where $d$ is the difference between two single determinations on the same sample and $n$ is the number of double determinations. The interplate reproducibility in terms of the relative standard deviation was for the different serum globulin fractions: $\gamma 3.7, \beta_{2} 2.9, \beta_{1}$ $3.4, \beta_{1}+\beta_{2} 2.7$, inter- $\alpha-\beta$ 10.3, $\alpha_{2} 6.4, \alpha_{1} 8.5$ and $\alpha_{1}+\alpha_{2} 4.6 \%$ respectively. An example of the reproducibility is illustrated in Fig. 1.

The material was analysed statistically by analysis of variance and Student's t-test.

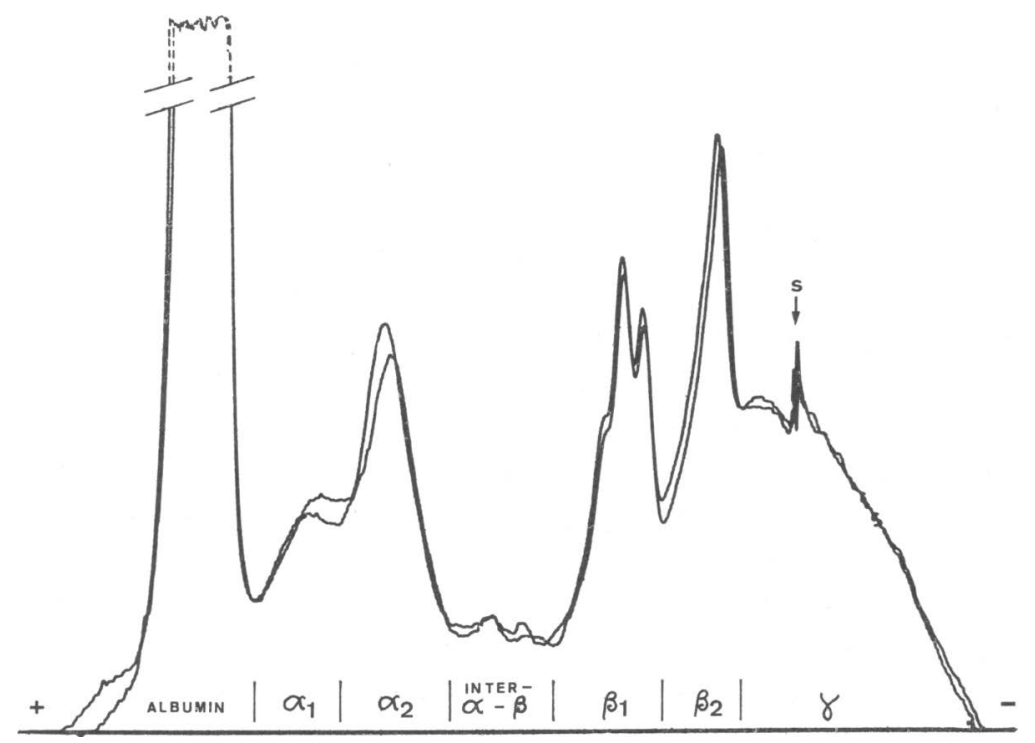

Figure 1. Electrophoretograms of proteins in blood serum from a normal cow. The two electrophoretograms are from the same sample but run on different electrophoresis plates (interplate variation). $\mathrm{s}=$ sample application slit. 


\section{RESULTS}

For all protein components the variation between cows was significantly greater than the variation between samplings of individual cows (Table 1 ).

Ta b l e 1. The serum protein pattern in healthy dairy cows. Mean and standard deviation from 11 samplings during about one year and statistical evaluation of the variation between cows in relation to that between samplings.

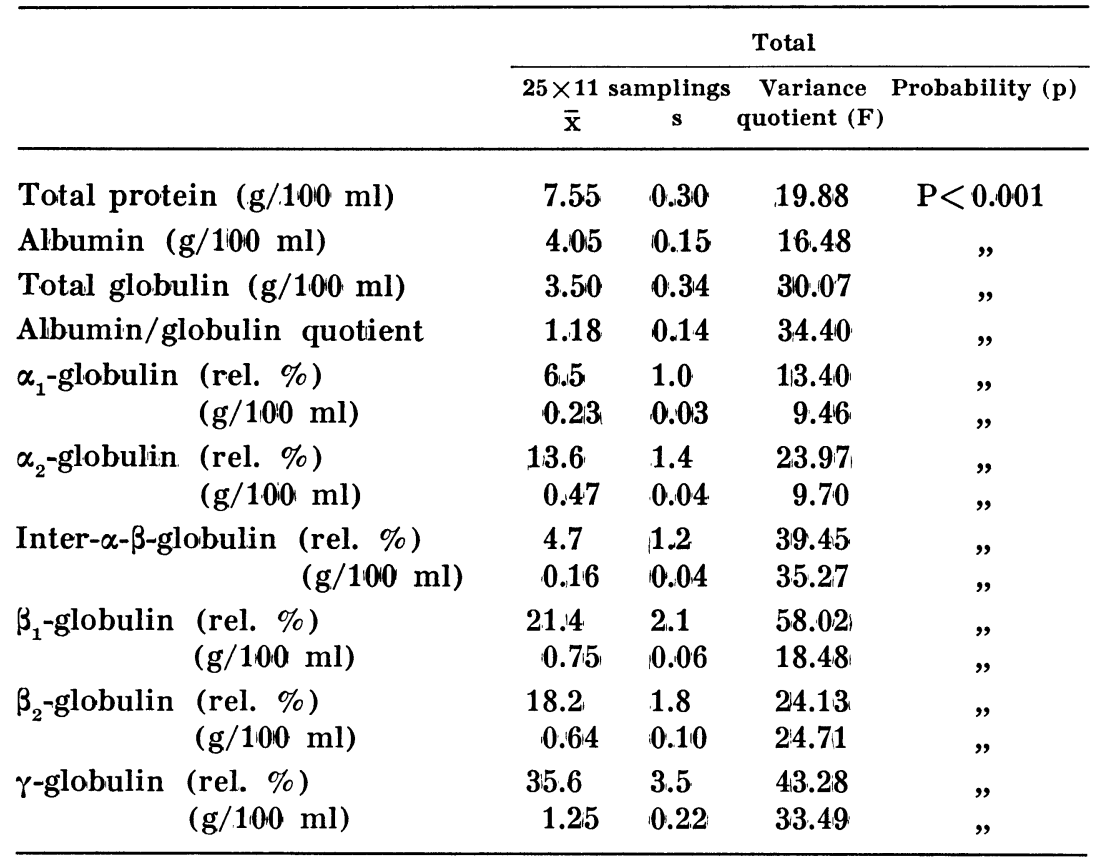

Between different age groups there were significant differences in total protein, total globulin and in absolute concentrations of $\beta_{1}$ - and $\gamma$-globulin. With rising age the absolute $\gamma$-globulin concentration rose significantly, which was reflected in increased concentrations of total globulin and total protein, with consequent lowering of the albumin/globulin quotient (Table 2).

Between stall feeding and grazing periods there were no significant differences in the concentrations of total protein, albumin or total globulin (Table 3 ). In the individual globulin fractions both the relative and the absolute concentration of $\alpha_{1}$ globulin was significantly lower during the grazing period. On the other hand the absolute concentrations of $\beta_{1}$ - and $\beta_{2}$-globulin, 


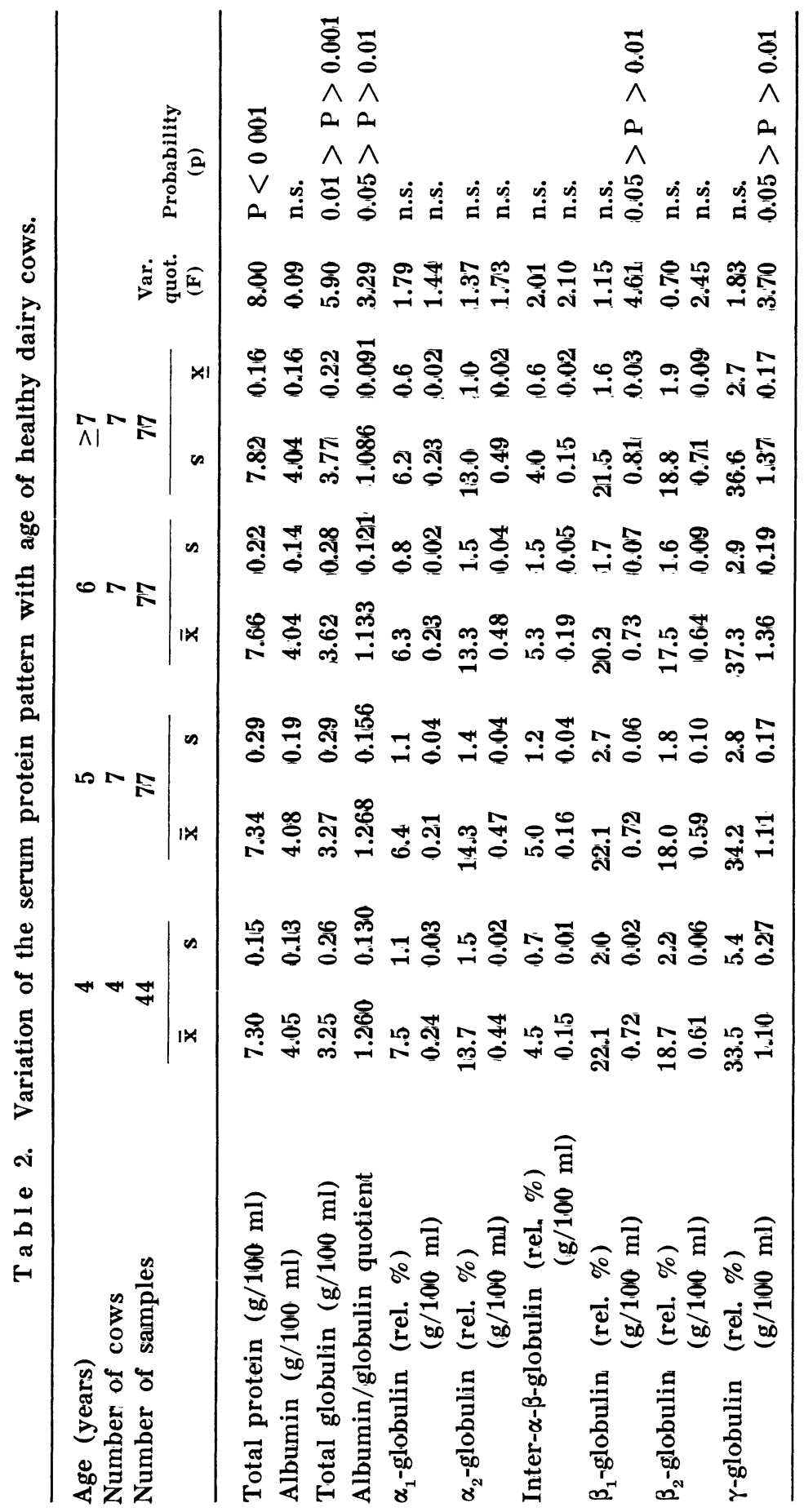


T a b l e 3. Seasonal variation of the serum protein pattern in healthy dairy cows.

\begin{tabular}{|c|c|c|c|c|c|c|}
\hline \multirow{3}{*}{$\begin{array}{l}\text { Number of cows } \\
\text { Number of samples }\end{array}$} & \multicolumn{4}{|c|}{ Seasonal variations } & \multirow[b]{3}{*}{ t-value } & \multirow[b]{3}{*}{ Probability (p) } \\
\hline & \multicolumn{2}{|c|}{$\begin{array}{l}\text { stall feeding } \\
\text { period } \\
25 \\
50\end{array}$} & \multicolumn{2}{|c|}{$\begin{array}{c}\text { grazing period } \\
25 \\
50\end{array}$} & & \\
\hline & $\overline{\mathbf{x}}$ & $\mathbf{s}$ & $\overline{\mathbf{x}}$ & $\mathbf{s}$ & & \\
\hline Total protein $(\mathrm{g} / 100 \mathrm{ml})$ & 7.53 & 0.35 & 7.66 & 0.43 & 1.153 & n.s. \\
\hline Albumin $(\mathrm{g} / 100 \mathrm{ml})$ & 4.03 & 0.18 & 4.00 & 0.28 & 0.549 & n.s. \\
\hline Total globulin $(\mathrm{g} / 100 \mathrm{ml})$ & 3.53 & 0.40 & 3.63 & 0.39 & 0.862 & n.s. \\
\hline Albumin/globulin quotient & 1.166 & 0.160 & 1.137 & 0.157 & 0.653 & n.s. \\
\hline $\begin{array}{ll}\alpha_{1} \text {-globulin } & (\text { rel. } \%) \\
& (\mathrm{g} / 100 \mathrm{ml})\end{array}$ & $\begin{array}{l}7.5 \\
0.26\end{array}$ & $\begin{array}{l}1.5 \\
0.05\end{array}$ & $\begin{array}{l}6.0 \\
0.22\end{array}$ & $\begin{array}{l}1.1 \\
0.04\end{array}$ & $\begin{array}{l}4.177 \\
4.081\end{array}$ & $\begin{array}{l}P<0.001 \\
P<0.001\end{array}$ \\
\hline $\begin{aligned} \alpha_{2} \text {-globulin } & (\text { rel. \%) } \\
& (\mathrm{g} / 100 \mathrm{ml})\end{aligned}$ & $\begin{array}{c}13.5 \\
0.47\end{array}$ & $\begin{array}{l}1.1 \\
0.04\end{array}$ & $\begin{array}{c}12.8 \\
0.46\end{array}$ & $\begin{array}{l}1.4 \\
0.05\end{array}$ & $\begin{array}{l}1.921 \\
0.963\end{array}$ & $\begin{array}{l}\text { n.s. } \\
\text { n.s. }\end{array}$ \\
\hline $\begin{aligned} \text { Inter- } \alpha-\beta \text {-globulin } & (\text { rel. } \%) \\
& (\mathrm{g} / 100 \mathrm{ml})\end{aligned}$ & $\begin{array}{l}4.8 \\
0.17\end{array}$ & $\begin{array}{l}1.4 \\
0.05\end{array}$ & $\begin{array}{l}4.5 \\
0.16\end{array}$ & $\begin{array}{l}1.0 \\
0.04\end{array}$ & $\begin{array}{l}0.793 \\
0.325\end{array}$ & $\begin{array}{l}\text { n.s. } \\
\text { n.s. }\end{array}$ \\
\hline $\begin{array}{ll}\beta_{1} \text {-globulin } & (\text { rel. \%) } \\
& (\mathrm{g} / 100 \mathrm{ml})\end{array}$ & $\begin{array}{c}21.2 \\
0.74\end{array}$ & $\begin{array}{l}2.3 \\
0.08\end{array}$ & $\begin{array}{c}22.1 \\
0.79\end{array}$ & $\begin{array}{l}2.1 \\
0.08\end{array}$ & $\begin{array}{l}1.308 \\
2.274\end{array}$ & $\begin{array}{l}\text { n.s. } \\
0.05>P>0.01\end{array}$ \\
\hline $\begin{array}{ll}\beta_{2} \text {-globulin } & (\text { rel. \%) } \\
& (\mathrm{g} / 100 \mathrm{ml})\end{array}$ & $\begin{array}{c}17.5 \\
0.62\end{array}$ & $\begin{array}{l}2.1 \\
0.11\end{array}$ & $\begin{array}{r}18.9 \\
0.68\end{array}$ & $\begin{array}{l}1.9 \\
0.10\end{array}$ & $\begin{array}{l}2.416 \\
2.183\end{array}$ & $\begin{array}{l}0.05>P>0.01 \\
0.05>P>0.01\end{array}$ \\
\hline $\begin{array}{ll}\gamma \text {-globulin } & (\text { rel. \% }) \\
& (\mathrm{g} / 100 \mathrm{ml})\end{array}$ & $\begin{array}{c}35.6 \\
1.26\end{array}$ & $\begin{array}{l}3.9 \\
0.25\end{array}$ & $\begin{array}{l}36.0 \\
1.30\end{array}$ & $\begin{array}{l}3.6 \\
0.24\end{array}$ & $\begin{array}{l}0.419 \\
0.504\end{array}$ & $\begin{array}{l}\text { n.s. } \\
\text { n.s. }\end{array}$ \\
\hline
\end{tabular}

as also the relative concentration of $\beta_{2}$-globulin, were significantly higher during the grazing period.

Between different pregnancy periods there were no significant differences in the concentrations of total protein, albumin or total globulin (Fig. 2). For the individual globulins significant differences were observed in the relative concentrations of $\alpha_{1}-, \beta_{2}-$ and $\gamma$-globulin (Fig. 2) and for the $\alpha_{1}$-globulin also in the absolute concentration (Fig. 3 ). The $\alpha_{1}$-globulin showed a slow continuous fall with progress of pregnancy, while the $\gamma$-globulin, reached a minimum after about one-third of the duration of pregnancy, thereafter increasing up to parturition. The fluctuation of the $\beta_{2}$-globulin was more irregular.

\section{DISCUSSION}

Electrophoretic analysis is valuable both for screening tests of the serum or plasma protein composition and for more pro- 


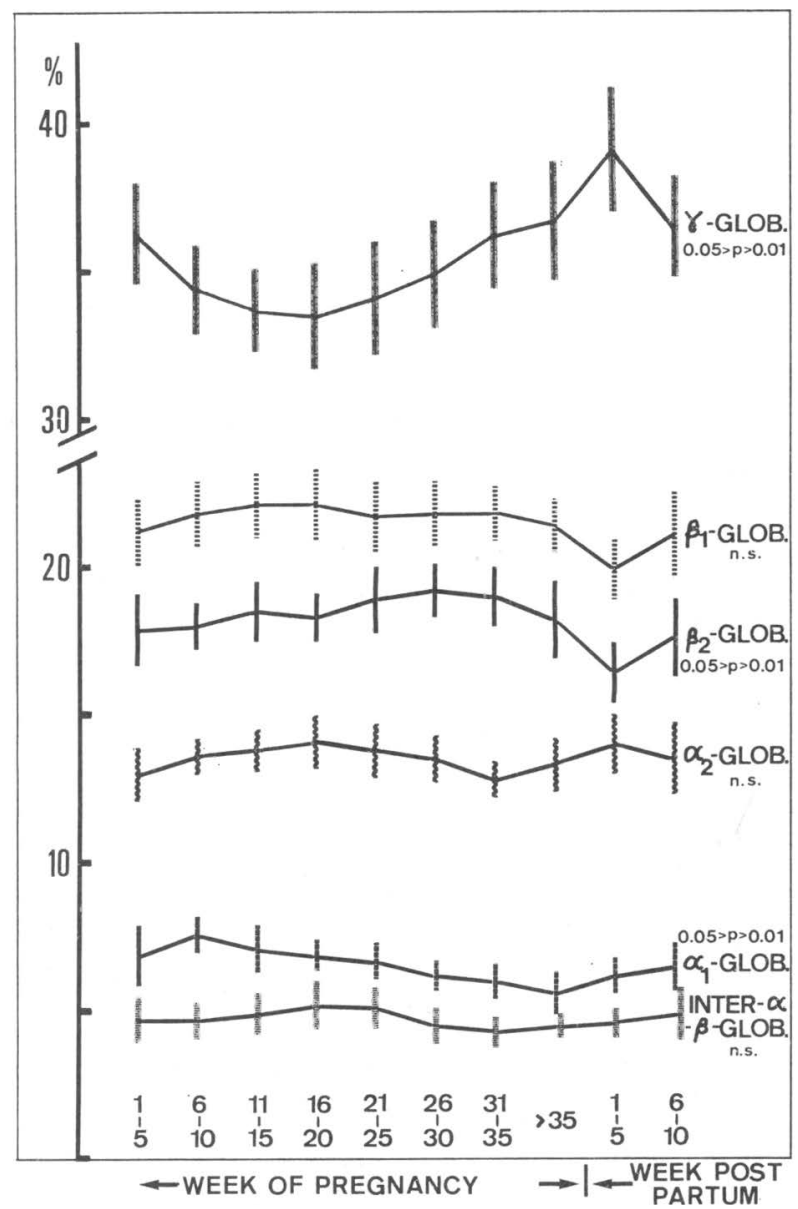

F i g u r e 2. Variation of the serum globulin pattern in healthy dairy cows for different stages of pregnancy and during the period immediately after calving (relative concentrations \%; $x \pm 95 \%$ C.I.).

found analysis, and as complement to specific analysis of individual proteins.

Strictly standardized analytical procedures and consideration as far as possible of the physiological variation are essential for a meaningful evaluation of changes in serum protein composition in an individual case of illness. Improved methods of analysis are important for minimizing the variation and the uncertainty in the determination technique. The agarose gel electro- 


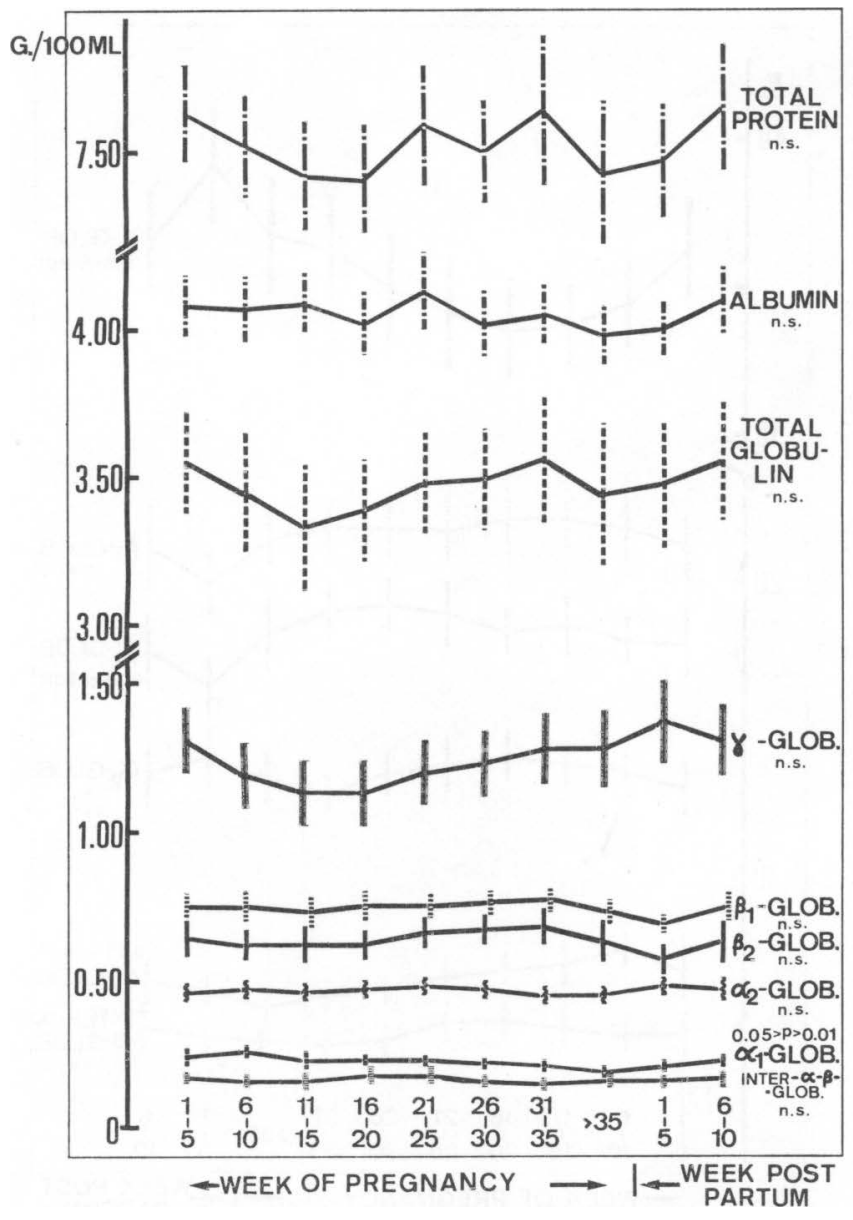

F ig u re 3. Variation of the serum protein pattern in healthy dairy cows for different stages of pregnancy and during the period immediately after calving (absolute concentrations, $\mathrm{g} / \mathrm{ml}$ serum; $\mathrm{x} \pm 95 \%$

C.I.).

phoresis method used in this study is distinctly superior to paper electrophoresis in this respect.

The establishment of normal values for the serum protein components in cattle involves many problems which have often been mentioned and discussed in the literature. The physiological variation is complicated and consists in differences between animals and fluctuations in the individual animal.

The variation with breed, age, stage of lactation and of preg- 
nancy is to some extent possible to illustrate, whereas variations caused by hereditary differences and by differences in general immunological status are more difficult to take into account.

The correlation between different factors of significance for the protein composition may be complicated and difficult to evaluate. Several authors (e.g. Payne et al. 1970, Hewett 1974), when using metabolic blood profile tests, have observed a great variation in the concentrations of total protein, albumin and globulin between herds. Differences in management technique and feeding may be regarded as important causes of variation in this respect. Payne et al. observed, for example, that hypoalbuminaemia occurred in herds with low protein intake. It has not been possible with the relatively laborious electrophoretic technique to investigate a material of a size which allows meaningful analysis of inter-herd variations. But it may be assumed that any such variations in globulin concentration are not caused to any great extent by differences in feeding but by a varying immunity situation. The globulin concentration is essentially an index of the immunological response to infection.

As regards breed variation, it has been assumed that no major differences in the individual electrophoretic protein fractions occur between most Swedish breeds of dairy cow. Some support for this assumption is found in a study of purchased animals (Liberg 1974), which showed no significant differences between Swedish red-and-white and Swedish Holstein Friesian cows for total protein, albumin or total globulin.

The age variation found accorded with that reported in the literature (e.g. Czernicki 1957, Matthaeus \& Straub 1965, Hewett). With rising age the $\gamma$-globulin concentration increased, and with it the total globulin concentration. The albumin concentration was unchanged, resulting in increase of the total protein concentration and lowering of the albumin/globulin quotient. The increase of $\gamma$-globulin, which consists of immunoglobulins, may be seen as an expression of successive increase of the specific immunity of the animal.

The variations during different stages of pregnancy were moderate. No significant differences were found in the concentrations of total protein, albumin or total globulin. On the other hand there were certain significant variations in the $\alpha_{1}-$, $\beta_{2}$ - and $\gamma$-globulin fractions. The changes in the $\gamma$ - and $\beta_{2}$-globulin fractions, however, were confined to percentual fluctua- 
tions, while for the $\alpha_{1}$-globulin the absolute concentration as well was affected. Several authors have observed great changes in the serum protein concentrations during the last stage of pregnancy. In 1956 Blakemore \& Garner reported significant changes of the $\gamma$-globulin levels in serum and lacteal secretion at parturition. Homologous bovine, radioactively labelled $\gamma$-globulins injected in the blood appeared in the precolostrum in the udder within $24 \mathrm{hrs}$. and was concentrated there at least 13 times. Larson \& Kendall (1957) observed that about 14 weeks before parturition the serum protein levels began slowly to increase, reaching a maximum about four weeks before parturition, thereafter falling to a minimum at parturition. These authors showed the changes in serum to be due to losses of $\beta_{2^{-}}$and $\gamma$-globulins to the colostrum. The variations of other serum proteins were more limited. These observations have later been confirmed by many authors, e.g. Dixon et al. (1961). The reason why this lowering of immunoglobulin was not recorded in the present study is presumably that most samplings were made closer to 35 weeks' pregnancy than to the time of parturition. Larson (1958) found that, even if the transport particularly of immunoglobulins from the blood to the colostrum starts roughly one month before parturition, the great change in serum does not occur until the very last days of pregnancy. In a study of purchased animals (Liberg) a significant lowering of the total globulin concentration was recorded for animals with more than 8.5 months' pregnancy, which lends additional confirmation to the findings of Larson \& Kendall and others.

As in the present study, Larson \& Kendall also found a continuous difficultly explainable lowering of the $\alpha_{1}$-globulin concentration with progress of pregnancy. They pointed out, however, that practically all blood globulin components in the newborn calf are $\alpha$-globulins and that components electrophoretically resembling the $\alpha$-globulins appear in the colostrum close to parturition.

By means of immuno-chemical determinations among other methods, Dixon et al. found that the $\gamma$-globulin level in serum rose quickly in the first weeks after parturition and that it often continued to rise slowly to a level exceeding that before parturition. A similar rising tendency was noted in the present study.

The variation between stall feeding and grazing periods for individual protein fractions is difficult to evaluate, but would 
appear to be attributable mainly to differences in nutrient content of the feed. The statistically very significant difference in $\alpha_{1}$-globulin concentration must especially be observed.

\section{REFERENCES}

Blakemore, F. \& R. J. Garner: The maternal transference of antibodies in the bovine. J. comp. Path. 1956, 16, 287—289.

Boguth, W.: Papierelektrophoretische Serumuntersuchungen bei Haussäugetieren. (Paper-electrophoretic serum-examinations in domestic mammals). Zbl. Vet.-Med. 1954, 1, 168—187, 311—329.

Carlström, G.: Studies on parturient paresis in dairy cows. IV. Calcium and proteins in bovine serum normally, after parturition, and in parturient paresis. Acta vet. scand. 1961, 2, 330-349.

Carlström, G. \& P. Liberg: Agarose gel electrophoretic separation of blood serum proteins in cattle. Acta vet. scand. 1975, 16, 520524.

Chopard, P.: Bestimmung der Eiweissfraktionen des Blutserums bei den Haustieren mit der Papierelektrophorese, unter Berücksichtigung verschiedener Faktoren. (Determination of blood serum protein fractions in domestic animals with paper electrophoresis, considering different factors). Schweiz. Arch. Tierheilk. 1954, 96, 252-260.

Czernicki, B.: Elektrophoretische Untersuchungen an Rinderserum. (Electrophoresis studies on cattle serum). Zbl. Vet.-Med. 1957, 4, 588-602.

Dixon, F. J., W. O. Weigle \& J. J. Vasquez. Metabolism and mammary secretion of serum proteins in the cow. Lab. Invest. 1961, 10, 216-236.

Doumas, B. T., W. A. Watson \& H. G. Biggs: Albumin standards and the measurement of serum albumin with bromcresol green. Clin. chim. Acta 1971, 31, 87-96.

$E k, N .:$ Studies on electrophoresis on cellulose acetate membrane of bovine serum proteins in healthy animals. Acta vet. scand. 1969, $10,118-126$.

Haraszti, J. \& G. Tölgyesi: Über den Einfluss von östrus und Kalben auf die Serumproteine der Kuh. (On the influence of estrus and parturition on cow serum proteins). Acta vet. Acad. Sci. hung. $1961,11,155-162$.

Heidler, W.: Papierelektrophoretische und populationsgenetische Untersuchungen am Blutserum von Kühen. (Paper electrophoretic and population genetic studies of the blood serum of cows). Arch. Tierzucht 1968, 11, 413-422.

Hewett, C.: On the causes and effects of variations in the blood profile of Swedish dairy cattle. Thesis, Acta vet. scand. 1974, Suppl. 50, $152 \mathrm{pp}$.

Irfan, M.: The electrophoretic pattern of serum protein in normal animals. Res. vet. Sci. 1967, 8, 137-142. 
Johansson, B. G.: Agarose gel electrophoresis. In C.-B. Laurell: Eler-trophoretic and Electro-Immuno-Chemical Analysis of Proteins. Scand. J. clin. Lab. Invest. 1972, 29, Suppl. 124.

Labouche, C.: Calcul d'erreurs dans l'interprétation quantitative des électrophorèses de sérum des bovidés domestiques. (The calculation of errors in the quantitative interpretation of the electrophoresis of the serum of domestic bovines). Ann. Biol. anim. $1962,2,251-263$.

Larson, B. L.: Transfer of specific blood serum proteins to lacteal secretions near parturition. J. Dairy Sci. 1958, 41, 1033-1044.

Larson, B. L. \& R. L. Hays: An explanation for bovine parturition edema and treatment with blood protein replacements. J. Dairy Sci. 1958, 41, 995-997.

Larson, B. L. \& K. A. Kendall: Changes in specific blood serum protein levels associated with parturition in the bovine. J. Dairy Sci. 1957, 40, 659-666.

Liberg, P.: Undersökningar över formolgelreaktionen och serumproteiner hos förmedlade kor och kvigor. (Investigations on the formolgel reaction and serum proteins in purchased cows and heifers). Svensk Vet.-Tidn. 1974, 26, 327-329.

Matthaeus, W.: Die Auftrennung der Serumproteine verschiedener Haussäugetiere in der Trägerelektrophorese. (Separation of the serum proteins from different domestic mammals by gel electrophoresis). Zbl. Vet.-Med. 1965, 12, 133-142, 189—203.

Matthaeus, W. \& O. C. Straub: Serumelektrophoretische und hämatologische Befunde bei gesunden, an Leukose und MKS erkrankten Rindern. (Serum electrophoretic and hematological findings in normal cattle and cattle suffering from leucosis and foot-andmouth disease). Berl. Münch. tierärztl. Wschr. 1965, 78, 421425.

McLennan, M. W. \& R. A. Willoughby: Observations of serum protein values of cows during estrus, lactation, parturition and milk fever. Canad. vet. J. 1973, 14, 2313-242.

Nilsson, T. \& B. Ảberg: Proteins and protein-bound carbohydrates in normal bovine serum. Nord. Vet.-Med. 1956, 8, 975-982.

Osbaldiston, G. W.: Serum protein fractions in domestic animals. Brit. vet. J. 1972, 128, 386-393.

Payne, J. M., S. M. Dew, R. Manston \& M. Faulks: The use of a metabolic profile test in dairy herds. Vet. Rec. 1970, 87, 150-157.

Perk, K. \& K. Loebl: Die Serum-Eiweissfraktionen im Rinderblut eine chemische und papierelektrophoretische Studie. (The serum protein fractions in cattle blood - a chemical and paper electrophoretic study). Schweiz. Arch. Tierheilk. 1959, 101, $548-557$.

Raphael, B. C., P. S. Dimick \& D. L. Puppione: Electrophoretic characterization of bovine serum lipoproteins throughout gestation and lactation. J. Dairy Sci. 1973, 56, 1411-1414.

Winkler, D.: Eiweissmikroelektrophorese am normalen Rinderserum. (Microelectrophoresis of normal cattle serum proteins). Dtsch. tierärztl. Wschr. 1955, 62, 515-517. 
Wünsche, H.-G.: Vergleichende papierelektrophoretische Untersuchungen an Abortus-Bang- und tuberkulosefreien klinisch gesund erschienenden Rindern verschiedenen Alters. (Paper electrophoretic comparison between clinically healthy cattle of different ages, all free from Abortus Bang and tuberculosis). Arch. exp. Vet.-Med. 1960, 14, 691-709.

Zimmerli, J.: Die Eiweissfraktionen im Blutserum des Rindes in Abhängigkeit von verschiedenen chronischen Krankheiten insbesondere der Tuberkulose. (The protein fractions in cattle blood serum in relation to different chronic diseases, especially tuberculosis). Z. Tierzücht. Züchtungsbiol. 1955, 64, 355-380.

\section{SAMMANFATTNING}

Agarosgelelektroforetisk fraktionering av serumproteiner hos vuxna nötkreatur. I. Undersökning av kliniskt friska kor.

För att bestämma normalvärden på serumproteiner vid använding av i första hand agarosgelelektrofores togs blodprov från 25 kliniskt friska mjölkkor av SRB-ras vid 11 provtagningstillfällen under c:a 1 år. Serumproteinerna undersöktes $i$ avseende på procentuell fördelning och absoluta koncentrationer. Följande parametrar studerades: totalprotein, albumin, totalglobulin, A/G-kvot, $\alpha_{1}-, \alpha_{2}^{-}$, inter- $\alpha-\beta-, \beta_{1}-, \beta_{2}-$ och $\gamma$-globulin. Materialet bearbetades statistiskt med avseende på variation mellan och inom kor, ålders-, dräktighets- och säsongvariation.

Av resultaten framgick att variationen mellan kor var signifikant större än den inom kor mellan olika provtagningstillfällen. Den viktigaste fysiologiska variationsorsaken var åldern. Äldre kor uppvisade signifikant förhöjda $\gamma$-globulinkoncentrationer. Variationen med säsong och dräktighetsgrad var mindre uttalad för flertalet serumproteinfraktioner. Undersökningsresultaten diskuteras i ljuset av relevant litteratur.

(Received December 1, 1976).

Reprints may be requested from: Per Libeng, the Research Station of the Veterinary Institute, S-532 00 Skara, Sweden. 